\title{
ISLAMIC FINANCIAL TECHNOLOGY TOWARDS THE ADVANCEMENT OF ISLAMIC BANKING IN INDONESIA
}

\author{
TEKNOLOGI FINANSIAL ISLAM \\ MENUJU KEMAJUAN PERBANKAN ISLAM DI INDONESIA
}

\section{Andi Zulfikar Darussalamª; Bambang Tutuko²; Ahmad Dahlan33; Ahmad Hudaifah"; Andi Darussalam Tajang 5}

\begin{abstract}
1aFaculty of Economics and Business Universitas Internasional Semen Indonesia, Jl. Veteran, Sidokumpul, Gresik, Kb. Dalem, Sidokumpul, Kec. Gresik, Kabupaten Gresik, Jawa Timur-Indonesia, e-mail: andi.darussalam@uisi.ac.id

${ }^{2}$ Faculty of Economics and Business Universitas Internasional Semen Indonesia, Jl. Veteran, Sidokumpul, Gresik, Kb. Dalem, Sidokumpul, Kec. Gresik,Kabupaten Gresik, Jawa Timur-Indonesia

${ }^{3}$ Faculty of Economics and Business Universitas Internasional Semen Indonesia, Jl. Veteran, Sidokumpul, Gresik, Kb. Dalem, Sidokumpul, Kec. Gresik, Kabupaten Gresik, Jawa Timur-Indonesia

${ }^{4}$ Faculty of Economics and Business Universitas Internasional Semen Indonesia, Jl. Veteran, Sidokumpul, Gresik, Kb. Dalem, Sidokumpul, Kec. Gresik, Kabupaten Gresik, Jawa Timur-Indonesia

5Pascasarjana UIN Alauddin Makassar, Jl. HM Yasin Limpo No.36, Samata-Gowa, Sulawesi Selatan, Indonesia
\end{abstract}

\begin{abstract}
Responding to the digital economy in the era of industrial revolution 4.0, the quality of sharia banking services in Indonesia is estimated and expected to increase significantly, in order to reach all levels of society, especially for people who live in the 3T area (terdepan/frontier, terluar/outermost, and terpencil/isolated). However, currently the quality of sharia banking services in Indonesia is not yet satisfactory, especially by people living in the 3T area. this research, trying to answer the challenge through a SWOT analysis of the application of financial technology policies in Islamic banks, with the hope of the quality of Islamic banking services can be improved and felt by all levels of Indonesian society and banking players can quickly understand and act. The management of Islamic banking management functions appropriately is based on an attitude of fear of Allah SWT, in the context of managing internal and external assets that include banking activities in a holistic manner. Thus, this study aims to analyze more deeply the strengths, weaknesses, opportunities, and threats (SWOT) of the application of Islamic banking financial technology (mobile banking) in Indonesia, the results showed a significant achievement compared to the previous year, even though in the global context, there were still many breakthroughs needed so that the $3 \mathrm{~T}$ community could utilize optimal Islamic banking services.
\end{abstract}

Keywords: Industrial Revolution 4.0, Digital Economy, Mobile Banking, Islamic Finance. 


\begin{abstract}
ABSTRAK
Menghadapi ekonomi digital di era revolusi industri 4.0, kualitas layanan perbankan syariah di Indonesia diperkirakan akan meningkat secara signifikan, guna menjangkau semua lapisan masyarakat, terutama bagi masyarakat yang tinggal di daerah 3T (terdepan, terluar, dan tertinggal). Namun, saat ini kualitas layanan perbankan syariah di Indonesia belum memuaskan, terutama oleh orang-orang yang tinggal di daerah 3T. Penelitian ini, mencoba menjawab tantangan melalui analisis SWOT dari penerapan kebijakan teknologi keuangan di bank syariah, dengan harapan kualitas layanan perbankan syariah dapat ditingkatkan dan dirasakan oleh semua lapisan masyarakat Indonesia dan pemain perbankan dapat dengan cepat memahami dan bertindak. Manajemen fungsi manajemen perbankan syariah secara tepat didasarkan pada sikap takut kepada Allah SWT, dalam konteks mengelola aset internal dan eksternal yang mencakup aktivitas perbankan secara holistik. Dengan demikian, penelitian ini bertujuan untuk menganalisis lebih dalam kekuatan, kelemahan, peluang, dan ancaman (SWOT) dari penerapan teknologi keuangan (mobile banking) perbankan syariah di Indonesia, hasilnya menunjukkan pencapaian yang cukup signifikan dibanding tahun sebelumnya, meski demikian dalam konteks global, masih diperlukan banyak terobosan agar masyarakat 3T bisa memanfaatkan layanan perbankan syariah yang optimal.
\end{abstract}

Keywords: Revolusi Industri 4.0, Ekonomi Digital, Mobile Banking, Keuangan Islam.

Andi Zulfikar Darussalam. 2018. Islamic Financial Technology Towards The Advancement of Islamic Banking in Indonesia . Jurnal Nisbah 4 (2): 171-181.

\section{INTRODUCTION}

The rapid development of science and technology in the digital era today has influenced the pattern of human behavior in accessing various information and various features of electronic services. One of the latest technological developments in Indonesia is Financial Technologies (FT) in banking institutions. According to the definition described by the National Digital Research Center (NDRC), financial technology is a term used to describe innovation in financial services, where the term derives from the words "financial" and "technology" (FT) that refer to finance. Innovation with a touch of modern technology (Sukma, 2016).

The concept of FT adapts technological developments combined with the financial fields of banking institutions, which are expected to facilitate more practical, safe and modern financial transaction processes, including digital-based financial services currently being developed in Indonesia, namely payment channel systems, digital banking, digital insurance online, Peer to Peer (P2P) Lending, and crowd funding (Siregar, 2016)

Deputy Director of the Directorate of Banking Licensing and Information, Tris Yulianta, revealed that banking institutions need to utilize the application of financial technology to improve the efficiency of operational activities and the quality of banking services for their customers, because the use of financial technology is in line with the increasing demand for online-based financial services and usage internet media to access digital data (Apriyani, 2016). This means that with the advancement of banking technology, time effectiveness can be 
accelerated in the banking transaction system among customers (Firmansyah and Widiati, 2016). The statement was also supported by a survey published by the Indonesian Internet Service Providers Association (APJII) in March 2015, which stated that the number of internet users in Indonesia increased from 71.9 million in 2013 to 88.1 million by the end of the year 2014, or around 34.9 percent of the current total population (Heriyanto, 2015).

In terms of numbers, the penetration of the use of digital technology in Indonesia has a large potential, even exceeding the population mix of other countries in the ASEAN region, and has changed people's behavior in almost all aspects of life, such as e-commerce, social interaction (social media), electronic books, electronic newspapers, public transportation (taxis and motorbikes), tourism support services, and financial technology (Siregar, 2016). Compared to the year 2014, which only reached 83.7 million users of financial technology, internet access in Indonesia has shown a significant increase (Julianto, 2016), although internet users increase every year, but the use of financial technology for access to banking services in Indonesia is still low. According to the survey conducted by Sharing Vision in 6 major banks in Indonesia, the number of Internet Banking users reached 5.7 million in 2012, the number of internet users increases, but when compared to the population, it is still low (MRI Writers Team, 2016)

In addition to the use of financial technology in banking that is still relatively low, other factors that make it difficult for Indonesian people to access banking services, especially in area 3T, are unequal access to banking services. Unequal access to banking services remains a problem that continues to be faced by banking institutions, especially in remote areas that are not reached by banking institutions and financial services, because of the condition of people who are not fully familiar with banking services and other financial services, so that they are potentially exploited by irresponsible parties (Habibi, 2016).

The principle of Islamic Economics encourages adherents to get and give mercy to all nature (rahmatan lil 'alamiin), one of which is to encourage technological advances that can bring closer to Allah SWT (Darussalam, 2017; Tutuko et.al., 2017) FT service quality studies mostly use quantitative data analysis to test the significance of the effect of service quality on the variables of satisfaction and adoption of financial technology, still lack of research using qualitative data analysis makes researchers interested in depth. This study uses qualitative data analysis to analyze customer perceptions of FT service quality, especially in $\mathrm{MB}$, so the formulation of the problem raised is, "how is the quality and effectiveness of mobile banking services for customers of Islamic banks in Indonesia when analyzed based on SWOT analysis?". The Sharia Bank examined in this study is Bank Syariah Mandiri which is the Best Bank in Digital Services in the Sharia Bank category 2017 (Tempo, Indonesia Banking School and Indonesia Banking Award, 2017), and the financial technology services studied are Mobile Banking (MB).

This research is expected to be a recommendation for sharia banking management to improve the quality of services or users of sharia banking services throughout Indonesia through the application of the latest financial technology.

\section{LITERATURE REVIEW AND RESEARCH METHODS}

\section{Definition of SWOT Analysis}

Strategic planning has an important role in formulating a company's business, directing the company's activities in the future, and improving company performance (Greenley, 1994). Strategic 
planning often involves several steps, one of which is examining the business environment (Weihrich, 1982). SWOT analysis has been assessed as the tool most often used to analyze the business environment (Glaister \& Falshaw, 1999). This is a simple and comprehensive analytical tool (Kotler and Armstrong, 2008) to examine the strengths, weaknesses, opportunities, and threats associated with the organization (Hung, 2013). Or in other words, S-W-O-T is used to assess the strengths and weaknesses of company resources and external opportunities and challenges (Hartono, 2005). According to David (2008) all organizations have strengths and weaknesses in the functional fields of business, which can be used as a basis for the objectives and determination of organizational strategies. Thus, SWOT analysis is a useful instrument in analyzing strategies (Osita, 2014), in the context of this article it is intended to assess the quality of banking services, so that it is expected to minimize weaknesses in banking institutions and minimize the impact of threats that arise and must be overcome. Through identifying strengths and weaknesses as a result of internal analysis, opportunities and threats as a result of the environment, organizations can develop strategies that rely on strengths to reduce perceived weaknesses, take advantage of identified opportunities and determine action plans to reduce or eliminate the effects of threats (koivkovi et al ., 2015).

\section{Financial Technology in Banking}

Referring to internet user data that has been described in the introduction, the use of digital technology in the daily lives of Indonesian people has changed people's behavior in almost every aspect of life, such as e-commerce, social digital interactions, electronics, mail electronic news, public transportation (taxis and motorbikes), tourism support services, and financial technology (Siregar, 2016).
The use of digital information technology has helped many Indonesians to run the economy more effectively and efficiently than before, especially in the financial and banking sectors (Margaretha, 2015). This was responded positively by Bank Indonesia through the provision of easy access and availability of financial services throughout Indonesia, where Bank Indonesia conducted preliminary studies and branchless banking trials launched in May, 2013. Experiments were carried out by 5 banks and, 2 telco in 5 provinces (West Java, Central Java, East Java, Bali and South Sumatra), the aim is to find out whether there are buying needs from the community and providers, the form of business models, and arrangements that are in accordance with Indonesia's conditions. Branchless banking is mainly done by utilizing highuse mobile phones, as well as working with local units or agents (Bank Indonesia, 2016). This is expected to further strengthen the performance of banks in providing services to customers through a financial information technology system. In line with the above opinion, financial technology is considered an important factor in encouraging the entry of financial digital banking in Indonesia (Julianto, 2016).

Sutojo (1997) states that electronic data processing technology, which has now evolved into financial technology, has helped banks in the speed and accuracy of business data processing operations and the marketing of their products. In line with the above opinion, the application of information systems is very influential in the banking industry, where the application of information systems in the banking industry has a huge impact considering the banking industry is one of the highest levels of industrial dependence on the activities of collecting, processing, analyzing and delivering reports information) needed to meet the needs of its customers (Kurnia et al., 2015). 
Indonesian banking still has the biggest influence in supporting financial system stability (Financial Service Authority, 2016), so that the application of financial technology is expected to maximize service in reaching every element of society, especially the people in 3T who are still inaccessible to the existence of branch offices. This is also supported by $0 J \mathrm{~K}$, which is currently developing a financial technology system to be used in services in the financial services industry, especially the application of banking services in Indonesia (Fajriah, 2016).

\section{Quality of Banking Services}

Quality is a dynamic condition that affects products, services, people, processes and environments that meet or exceed expectations (Tjiptono, 2001). While the definition of service according to Kotler (2002) is any action or activity that can be offered by parties to other parties, which is basically intangible and does not result in any ownership. The purpose of service quality can be defined as an effort to meet the needs / desires of consumers in the balance of expectations of consumers (Tjiptono, 2001). Or with another statement, the notion of service quality is a word that for service providers is something that must be done well (Supranto, 2006).

The study of the quality of banking services can be identified by comparing customer perceptions of the services they receive, in accordance with banking service quality standards that refer to customers, if banking services are accepted or perceived by customers according to what is expected, then the service quality is good or high quality and if the service level received by the customer is lower than expected, then the quality of banking services can be perceived as poor or of low quality. Thus, the perceptions shown by customers will affect their loyalty to the bank and will convey perceptions to other customers. This means that the perceptions shown by customers will directly affect customer loyalty (Nursiana, 2015).

Customers tend to be willing to share their positive experiences with others (Tobing: 2016) and assessing the quality of banking services can be observed based on the dimensions of service quality or commonly called service quality. Service quality is one of the main factors that has influenced consumer satisfaction with banking institutions, providing the best service to customers by banking institutions is very necessary to maintain customer loyalty and bank credibility.

\section{Research Methods}

The research method used is descriptive qualitative. Qualitative descriptive research is intended to collect actual and detailed information, identify problems, make comparisons or evaluations, and determine what others do in dealing with problems and similar learning from their experience to determine future plans and decisions (Suyanto and Sutinah, 2006). Thus, qualitative descriptive research is to describe the response to a situation or event, so it has not explained the causality relationship and to test the hypothesis. The object of the research is informant perception (i) on aspects of the use of MB services related to security, reliability, responsiveness, physical ability, and guaranteed service. Data was collected through interviews with 10 informants from customers using Bank Syariah Mandiri (BSM) Mobile Banking which was utilized or observed during the period of October 1 to November 25, 2018.

Table 1. Informants from Customers Using Bank Syariah Mandiri (BSM) Mobile Banking

\begin{tabular}{|l|l|l|l|}
\hline $\begin{array}{l}\text { Infor } \\
\text { man }\end{array}$ & $\mathrm{M} / \mathrm{F}$ & Job & $\begin{array}{l}\text { Duration of } \\
\text { use }\end{array}$ \\
\hline 1 & $\mathrm{M}$ & Private S & 1 month \\
\hline 2 & $\mathrm{~F}$ & Housewife & 2 months \\
\hline 3 & $\mathrm{M}$ & Lecturer & 2 months \\
\hline 4 & $\mathrm{~F}$ & Private S & 3 months \\
\hline 5 & $\mathrm{M}$ & Private S & 7 months \\
\hline
\end{tabular}




\begin{tabular}{|l|l|l|l|}
\hline 6 & F & Lecturer & 9 months \\
\hline 7 & M & Private S & 1 year \\
\hline 8 & F & Private S & 2 months \\
\hline 9 & M & $\begin{array}{l}\text { Entrepreneu } \\
\text { r }\end{array}$ & 3 months \\
\hline 10 & F & Private S & 7 months \\
\hline
\end{tabular}

\section{Data collection technique}

Data collected through in-depth interview methods, to receive an overview of the quality of MB services taken from informants / customers. Interviews with open questions that allow other questions to take place during the interview to deepen the informant's answers.

\section{Data analysis technique}

Data collected after the interview was carried out data reduction by selecting and sorting the results of interviews in accordance with the main objectives of the study, after data reduction data display was performed, namely grouping interview results based on the variables studied, then drawing conclusions using a constant comparative methodology. Constant comparative methodology applying intuitive, inductive logic and interpretation. The aim is to compare and find relationships between events throughout the study (Offstein et al, 2004). Conclusion as the purpose of this study is to explore the customer's perception of the quality of FT services in Islamic banks and the underlying factors.

\section{RESEARCH RESULT AND DISCUSSION}

\section{SWOT analysis}

\section{a) Strength Analysis}

The results of interviews with customers gave rise to several strengths in MB services, first is the opportunity for industrial revolution 4.0 to enable the advancement of financial technology facilities in the banking sector, especially in $\mathrm{MB}$ indirectly to advance the $3 \mathrm{~T}$ area and economy in various areas far from urban areas. Second, MB services make it easy for customers to make transactions anytime and anywhere (mobility), enough to have a cellphone (Android / iPhone) and the internet, allowing to reach groups of people who are not served by banking branches (3T), the price of mobile phones is currently enough affordable, so the potential for MB services in the future is quite large.

Third, the application of MB can save operational costs and banking marketing costs, because banking institutions can collaborate with financial technology service providers (Fintech) in operating and offering banking products to the public. Fourth, service access transactions with a nominal amount are quite large, this will be different if done in a conventional way, which is to bring cash in hand, of course for some people to worry if criminal actions approach them at any time. Fifth, the service features variant that is quite complete and widely known by the public, although not yet maximized by its users. Sixth, institutions such as the LPS (Deposit Insurance Agency) managed by the government can be a safeguard for customers who are worried about FT crime in the banking sector. Seventh, MB services can be accessed through various types of technological devices such as Android and iPhone, because reliability in MB services plays a role in customer satisfaction, and this lies in how far the available technology infrastructure is able to be used and available in various circumstances.

Eighth, all system processes in BSM $\mathrm{MB}$ are based on Islamic values such as anti-maghrib (maysir, gharar, riba and bathil) and prohibit activities that are prohibited by Islam. Islamic features such as; payment of zakat and infaq, Islamic advice (wisdom), prayer times and others are a plus for MB BSM compared to conventional ones, especially the majority of the population in Indonesia are Muslim. Brief information about MB BSM features:

a. Account info = balance information, mutation list, portfolio information.

b. Transfer = BSM, non-BSM, QR Pay. 
c. Payment $=$ PLN, Telephone / HP / TelkomPay, Institution / Academic, Tickets, Insurance, Zakat / Infaq.

d. Purchases = HP vouchers, prepaid PLN, E-Money.

e. QR pay.

f. Open account = Mabrur Savings (Hajj),

g. The nearest ATM and BSM Branch location.

h. Favorite menu.

i. Social media and call center.

j. Foreign exchange info and transactions.

\section{b) Weakness Analysis}

Some of the weaknesses of the interviews with customers, first are the inequality of Communication Technology infrastructure that has not been evenly distributed between regions, especially to 3T regions, causing the community to have difficulty in conducting online transactions (eg delays in access to transactions), so that technology services have not been optimal. Second, the emergence of online crime, such as tapping and breaking into account (cybercrime) in transactions, makes people a little hesitant to conduct MB transactions, so that not a few of them still hope that there are branch offices of banking institutions present in their area, usually experienced by baby boomers, where the average has a lack of digital literacy.

Third, banks that work with FT providers do not necessarily have licenses systematically and legally, so that practices of abuse of authority or irregularities are possible which can actually harm the banking institutions themselves. Fourth, public knowledge regarding financial technology that is relatively low allows them to not get the maximum access to services, so the role of banks, OJK, BI, educational institutions and others is very much needed in the dissemination and education of safe use of FT. Fifth, service tariffs are less competitive, this can be illustrated how much the costs incurred by customers in a transaction such as buying PLN credit tokens which are quite expensive compared to other technology services.

Sixth, customers sometimes complain about the complexity of accessing $\mathrm{MB}$ service features, frequent application errors, sometimes transactions often force close themselves, errors when checking balances and buying credit and sometimes failing to send proof of transfer. Seventh, there is no chat feature between customers and banks in MB, this can minimize customers making mistakes. The information assistance aspect is the customer's expectation relating to the speed of the bank responding and serving customers, which can be seen from the benefits and quality of interaction, by providing features that will enable customers to secure MB services, and this will affect good quality by answering customer needs (Mahfooz, 2013). Eighth, some service features that according to customers have not been maximal are: a) unable to transfer to BSM virtual account; b) payment options are still lacking, such as there are no payments for PDAM, BPJS, KAI and others which are the customer's daily needs; c) real-time credit notification facilities (incoming and out of funds) are expected; d) purchase of cellular credit, not all cellular telephone providers are provided; e) there is no multipayment menu, such as Lazada, Bukalapak, GoPay and others.

\section{c) Opportunity Analysis}

The interview results show several opportunities, first is the 4.0 industrial revolution entered in various sectors, including in banking, public awareness is slowly starting to grow to transact more with $\mathrm{MB}$, because it is considered easy, safe and comfortable (mobility). Second, the great opportunity in banking digitalization, requires the government through the Financial Services Authority (OJK) to create and supervise banking financial regulations and transactions, so as to minimize criminal acts and public concerns in using banking FT services. Third, communication features with 
banks, such as chatting in the $\mathrm{MB}$ application, are expected by customers to reduce errors in transactions. A simple and clear help menu on MB allows customers to easily make transactions and increase long-term customer satisfaction (Waithaka and Nzeveka, 2015). Fourth, the design of the MB feature is expected to be clearer, more interesting and easier so that customers remain loyal in the use of MB. The bank's strategy in FT services includes the development of services, such as security, speed of access, guarantee of transactions, self-information protection which all of these factors can increase customer confidence (Al-Smadi, 2012).

Fifth, product creation and promotion packed with attractive programs, can generate customer interest in registering and transacting to banks. Sixth, customer participation in securing MB transactions is like giving an opportunity to verify each transaction that will be carried out with up-to-date and maximum technology (eg sms, call, token \& finger / face recognition), because security is a significant factor in increasing customer confidence to continue to be loyal to the bank (Lee, 2009; Nasri, 2011; Perkins, 2013), the consequence is that banks need research and appropriate solutions on how banks can improve security in other ways that do not cause complexity or complexity in accessing MB services that can result in slow and reduced customer convenience. Security can be categorized into, 2 parts, first security system, where MB applications can serve customers with multiple security such as password change facilities, block accounts if at any time theft of mobile phones occurs. Second, data protection, namely maintaining the confidentiality of customer data (privacy) and being misused by certain individuals.

Seventh, educating how to use MB safely is the answer of many customers in the security and convenience of transactions. The low quality of technology literacy by customers causes the low use of $\mathrm{MB}$, so that consumer knowledge related to the use of information technology can influence their daily use, so that the depth of experience causes customers to be loyal to the bank (Nasri, 2011; Saeidipour, 2013; Al-Smadi, 2012). Eighth, qualified IT infrastructure can maximize service access such as the speed of the feature process, the faster access, the more customers feel the ease of using it, because consumers can save time.

Ninth, national or international SOPs and Standards can maintain banking credibility, certification and good and proven human resources and infrastructure can generate trust in customers. The procedures and principles of responsibility involving all processes for customer and bank interactions such as security procedures, procedures for receiving complaints, registration procedures, password reset procedures and others, are obligations that must be provided and carried out properly by the customer and the bank itself. Tenth, human resources with IT background, data and communication analysis are needed by customers, IT reliability is felt with ease of service access while data and communication analysis capabilities can facilitate feature analysis and interaction with customers both online and offline.

Today many banks think out of the box in maximizing their services, if generally customers who come to the bank office, currently bank employees who come to customers to explain and offer bank facilities owned to maximize customer financial management. Knowledge and skills of banking staff can have an impact on the ability of banks to receive, process and provide solutions.

\section{d) Threats Analysis}

First, technological advances without the improvement in the quality of qualified human resources will be a problem in serving the community. Second, globalization and openness allow foreign banks with financial technology that might be more powerful and could threaten 
national banking. Third, a country's political environment is quite influential in the economic investment climate, including banking activities, because high inflation can occur, so banks are expected to prepare preventive and curative strategies when this happens.

Fourth, theft of privacy data, by internal and external companies. Data protection aims to protect customers from leakage and disruption of customers' personal data. Bank failures in protecting data security and privacy can make a bank's reputation worse (Folake, 2013). Informants who are not directly connected to bank staff (online) can trigger a security threat which is a matter of great concern, potentially causing losses due to fraud or hacker attacks, this was also expressed by Lee (2009) and Folake (2013). Fifth, aside from the security system in MB services (internal), it is also necessary to secure banking transaction education, such as not transacting in public places, it is feared that username and password can be easily seen, and other ways caused by negligence from the customers themselves. Therefore, the level of customer complaints on security issues experienced is an important indicator to recognize how far the problem and security disturbances are felt. Sixth, IT infrastructure is also feared to affect the performance of services, because the guarantee of stability and security creates customer confidence (AlFahim, 2013).

\section{CONCLUSION AND IMPLICATIONS}

Today, Islamic banking financial technology is far better than before, so that it can reach 3T (Leading, Remote and Outermost) areas. The SWOT analysis above shows how financial technology with MB services (Mobile Banking) can improve customer effectiveness and efficiency. Globalization has been opened, Bank BSM and other Islamic banking are expected to be able to compete with other National and International Conventional
Banks. The application of FT in banking has many advantages, but still not all Indonesian people can maximize it. Efforts from the government, academics, banking and others in the dissemination and education of the community are quite urgent. Finally, this study has limitations, therefore further research is highly recommended, especially in developing sharia-based financial technology.

\section{REFERENCES}

Al-Fahim, N.H. (2013) An Exploratory Study of Factors Affecting the Internet Banking Adoption. Global Journal of Management and Business Research, 13(8), 22-32.

Annual report BI (2018) accessed 22 November 2018. https://www.bi.go.id/id/publikasi/l aporan-tahunan/bi/Default.aspx

Cardao-pito, T. and Baptista, D. (2017) 'Portugal's banking and financial crises: unexpected consequences of monetary integration?', Journal of Economic Policy Reform. Routledge, 7870, pp. 1-27. doi: 10.1080/17487870.2016.1181551.

Darussalam, A. Z. and Malik, A. D. (2017) 'Konsep Perdagangan dalam Tafsir Al-Mishbah (Paradigma Filsafat Ekonomi Qur'ani Ulama Indonesia)'. Jurnal Al-Tijarah, 3(1), pp. 45-64.

David, F. R (2006) Manajemen strategis. Edisi ke Sepuluh, Jakarta: Penerbit Salemba Empat.

Firmansyah, Widiati (2016) Maksimalisasi nilai perbankan syariah melalui teknologi pelayanan nasabah terkini. Jurnal Keuangan dan Perbankan 20 (2): 274-281.

Folake, N.P. (2013). The Impact of Trust Antecedents of Internet Banking in Nigeria. International Journal of Economic and Business Management, 2(2), 19-24

Glaister, K. W., \& Falshaw, J. R. (1999). Strategic planning: Still going strong? Long Range Planning,32(1), 107-116 
Greenley, G. E. (1994). Strategic planning and company performance: An appraisal of the empirical evidence.Scandinavian Journal of Management,10(4), 383-396.

Habibi, Y. (2016). Refleksi setahun laku pandai. Republika. Accessed 7 April 2016. http://www.republika.co.id.

Hartono, J. 2005. Sistem informasi strategik untuk keunggulan kompetitif. Yogyakarta: Penerbit Andi Offset.

Heriyanto, T. 2015. Pengguna internet Indonesia capai 88,1 juta. $C N N$ Indonesia. Accessed 26 March 2015. http://www.cnnindonesia.com.

Hung, K. (2013) 'Understanding China's Hotel Industry: A SWOT Analysis Understanding China's Hotel Industry: A SWOT Analysis', Journal of China Tourism Research,9: 81-93, $20138160 . \quad$ doi: 10.1080/19388160.2013.756771.

Julianto, P. A (2016) "Fintech", cara perbankan penuhi kebutuhan nasabah. Kompas. Accessed 25 November 2018. http://bisniskeuangan.kompas.com.

Kotler, P (2002) Manajemen pemasaran di indonesia: Analisis, perencanaan, implementasi dan pengendalian. Jakarta: Penerbit Salemba Empat

Kotler, P., dan G. Armstrong (2008) Prinsip-prinsip pemasaran jilid 1. Jakarta: Penerbit Erlangga.

Lee, M. (2009) Factor Influencing the adoption of internet banking: An Integration of TAM dan TPB with perceived risk and perceived benefit. Electronic Commerce Research and Applications, 8(3),130-141

Mahfooz, Y., M. Al-Motairi, \& F. Ahmad, A. Khan. (2013). A Study of the Service Quality Issues of Internet Banking in Non-Metro Cities of India. Journal of Advanced Management Science, 1(1), 75-79.

Margaretha, F (2015) Dampak electronic banking terhadap kinerja perbankan Indonesia. Jurnal Keuangan dan Perbankan 19 (3): 514-524.
MRI. (2018) Prospek bisnis e-banking. Buletin MRI. Accessed 22 November 2018. http://www.mri-researchind.com.

Nursiana, A. 2015. Pengaruh internet banking, kualitas layanan, reputasi produk, lokasi, terhadap loyalitas nasabah dengan intermediasi kepuasan nasabah. Jurnal Keuangan dan Perbankan 19 (3): 450-462.

Offstein E.H., M.B Larson, A.L McNeil, \& H.M Mwale. (2004). Are We Doing Enough for Today's Graduate Students? The International Journal of Educational Management, 18(7), 396-407

Osita, I. C. (2014) ‘Organization's stability and productivity: the role of SWOT analysis an acronym for strength, weakness, opportunities and threat', International Journal of Innovative and Applied Research, Volume 2, Issue (9): 23- 32 pp. 23-32.

Siregar, A (2016) Financial technology tren bisnis keuangan ke depan. Infobanknews. Accessed 14 April 2016. http://infobanknews.com

Sukma, D (2016) Fintechfest, mempopulerkan teknologi finansial di Indonesia. Arena LTE. Accessed 24 Agustus 2016. Tersedia di http://arenalte.com.

Supranto, J. (2006) Pengukuran tingkat kepuasan pelanggan. Cetakan ke Tiga, Jakarta: Penerbit Rineka Cipta.

Sutojo, S (1997) Manajemen terapan bank. Jakarta: Pustaka Binaman Pressindo.

Suyanto, B., dan Sutinah (2006) Metode penelitian sosial. Jakarta: PT Kencana Persada.

Tempo, Indonesia Banking School (2018) Indonesia Banking Award. accessed $23 \quad$ November 2018. https://bisnis.tempo.co/read/90887 6/inilah-peraih-indonesian-bankingaward-2017/full\&view=ok

Tjiptono, F. (2001) Strategi pemasaran. Edisi ke Satu, Yogyakarta: Penerbit Andi Offset. 
Tobing, Fathorazzi, \& Wulandari (2016) Model inovasi sistem pemasaran perbankan syariah berbasis floating market untuk penciptaan daya saing (model of islamic banking marketing innovation systems based on floating market for creation competitiveness). Jurnal Keuangan dan Perbankan 20 (1): 75-83.

Tutuko, B., Hudaifah, A. and Zulfikar, D. (2017) 'Structuring Model for Corporate Productive Cash- Waqf in Indonesia (A Case Study of PT.
Semen Indonesia)'. Journal of Islamic Finance, Special Issue, pp. 163-173.

Weihrich, H. (1982). The TOWS matrix-A tool for situational analysis. Long Range Planning, 15(2), 54-66.

Živkovi, Ž. et al. (2015) 'Analytical Network Process in the Framework of SWOT Analysis for Strategic Decision Making (Case Study: Technical Faculty in Bor, University of Belgrade, Serbia)', Acta Polytechnica Hungarica. 12(7), pp. 199-216. 